\title{
MOVEMENT UNDERTAKEN BY NEWLY GRADUATED NURSES TOWARDS THE STRENGTHENING OF THEIR PROFESSIONAL AUTONOMY AND TOWARDS PATIENT AUTONOMY
}

\author{
Heloisa Wey Berti ${ }^{1}$ \\ Eliana Mara Braga ${ }^{2}$ \\ Ilda de Godoy ${ }^{3}$ \\ Wilza Carla Spiri ${ }^{2}$ \\ Silvia Cristina Mangini Bocchi ${ }^{2}$
}

Berti HW, Braga EM, Godoy I, Spiri WC, Bocchi SCM. Movement undertaken by newly graduated nurses towards the strengthening of their professional autonomy and towards patient autonomy. Rev Latino-am Enfermagem 2008 março-abril; 16(2):184-91.

This study involved newly graduated nurses performing in a public hospital and aimed at apprehending how they interpret the reality of their practice as well as their knowledge and experiences; at identifying and problematizing aspects related to the caregiving practice in terms of compliance with the autonomy bioethical framework and at pointing out ways to overcome the problems identified. The strategy adopted for data collection was the focal group and the theoretical framework was based on the Grounded Theory. Two phenomena emerged from the results: 1) Perceiving the fragility of nurse and patient autonomy and 2) Moving towards the strengthening of nurse and patient autonomy. This allowed for the identification of the core category: movement undertaken by newly graduated nurses towards the strengthening of their professional autonomy and towards patient autonomy. Understanding the experience enabled us to expand the knowledge concerning newly graduate nurses' coping, thus favoring our action as nursing professors.

DESCRIPTORS: professional autonomy; nursing; hospital care; ethics

\section{PERCEPCIÓN DE LOS ENFERMEROS RECIÉN GRADUADOS SOBRE SU AUTONOMÍA PROFESIONAL Y SOBRE EL PROCESO DE LA TOMA DE DECISIONES DEL PACIENTE}

El estudio fue realizado entre los enfermeros recién graduados que actúan en un hospital público con los objetivos de describir la percepción que tienen sobre su autonomía profesional y sobre el proceso de toma de decisiones del paciente. La estrategia adoptada para obtener los datos fue la de grupo focal y el marco metodológico la Grounded Theory. De los resultados surgieron dos fenómenos: 1) Percibiendo la fragilidad de la autonomía del enfermero y la del paciente. 2) Moviéndose en dirección a fortalecer la autonomía del enfermero y del paciente. Fue identificada la categoría central: movimiento emprendido por enfermeros recién formados en dirección a fortalecer la autonomía profesional y la autonomía del paciente. La comprensión de la experiencia permitió ampliar el conocimiento sobre los enfrentamientos de los enfermeros recién formados, lo que favoreció nuestra actuación como profesores de enfermería.

DESCRIPTORES: autonomía profesional; enfermería; asistencia hospitalaria; ética

\section{PERCEPÇÃO DE ENFERMEIROS RECÉM GRADUADOS SOBRE SUA AUTONOMIA PROFISSIONAL E SOBRE O PROCESSO DE TOMADA DE DECISÃO DO PACIENTE}

O estudo foi realizado junto a enfermeiros recém-graduados que atuam em um hospital público com os objetivos de descrever a percepção destes sobre sua autonomia profissional e sobre o processo de tomada de decisão do paciente. A estratégia adotada para obtenção dos dados foi a de grupo focal e o referencial metodológico a Grounded Theory. Dos resultados emergiram dois fenômenos: 1) Percebendo a fragilidade da autonomia do enfermeiro e do paciente. 2) Movendo-se em direção ao fortalecimento da autonomia do enfermeiro e do paciente. Isto possibilitou a identificação da categoria central: movimento empreendido por enfermeiros recém formados em direção ao fortalecimento de sua autonomia profissional e da autonomia do paciente. A compreensão da experiência nos permitiu ampliar o conhecimento sobre os enfrentamentos dos enfermeiros recém formados, favorecendo nossa atuação como professores de enfermagem.

DESCRITORES: autonomia profissional; enfermagem; assistência hospitalar; ética

${ }^{1}$ PhD in Public Health, Faculty, e-mail: weybe@uol.com.br; ${ }^{2}$ PhD in Nursing, Faculty, e-mail: elmara@fmb.unesp.br; wilza@fmb.unesp.br; sbocchi@fmb.unesp.br;

${ }^{3}$ PhD in Tropical Diseases, Faculty, e-mail: degodoy@fmb.unesp.br. Sao Paulo State University "Júlio de Mesquita Filho", Medical School at Botucatu, Brazil. 


\section{INTRODUCTION}

Nurses' commitment to the nursing practice requires permanent training as well as the development of consciousness and ethical sensitivity for making necessary and appropriate decisions. During the decision-making process, nurses can control the technical aspects of their practice, thus delimiting what is inherent in nursing so as to choose the best ways to perform in patient care ${ }^{(1)}$.

Hence, nurses use their autonomy and face dilemmas and moral conflicts that frequently arise in everyday nursing practice ${ }^{(2)}$

Bioethics, especially disseminated through the publication of its four principles by Beauchamp and Childress - Autonomy, Beneficence, Nonmaleficence and Justice, has been an important tool to analyze the dilemmas and moral conflicts emerging in the routine practice of health care providers.

Autonomy, one of the bioethical principles, is the concept on which this study has focused.

Autonomy means the capacity of human rationality to create laws for itself. "It is the capacity of self-government, of making coercion-free choices and assuming risks for such choices ${ }^{\prime \prime 3)}$.

In the health care professional/patient relationship, autonomy presupposes competence and freedom to make conscious choices from possible options. It is the nurse's responsibility to provide all necessary explanations concerning a given situation and the risks involved in various alternative choices, so that all possibilities can be acknowledged and the choice that best meets one's needs is made feasible. The patient is aware of himself and of his needs, and the professional masters the knowledge necessary for identifying the patient's problems and for the implementation of procedures to solve them. Both the health care provider and the patient must participate in the decision-making process ${ }^{(4-5)}$.

Understanding autonomy as a value means overcoming authoritarian or paternalistic attitudes which still permeate the relations among health care professionals and between the latter and their patients $^{(4-6)}$.

The exercise of autonomy by nurses has been regarded as complex due to influences from the social structures in which their work is developed and from the barriers imposed by such structures. Withstanding to certain influences and breaking barriers that hinder the nurse's autonomous practice enables his redemption and strengthens relations among health care professionals, patients and relatives ${ }^{(7-8)}$.

On the other hand, patients' rights are, many times, not observed, and the exercise of their autonomy is not valued. Citizenship, as the patient's fundamental right, is often denied. It should be understood as an indicator of the quality of health care services, since it is related to autonomy, privacy and professional confidentiality ${ }^{(5,8)}$.

Discussing and analyzing nursing care in light of the bioethical principle of autonomy simultaneously mean reflection and action in everyday situations that require analysis and decision-making.

As professors in a nursing undergraduate program, we understand that the nurse will be prepared for professional practice if he, concomitantly with the development of technical competence, is trained to recognize ethical conflicts, critically analyze their implications and use his sense of moral responsibility to make decisions regarding human life.

Our commitment is not fulfilled when we complete the education of our students, but it extends to the professionals involved with nursing care in our city and region through the commitment we have taken to our population's health care.

Therefore, because we believe that a problematizing analysis of health care provision by newly graduated nurses is opportune, we have proposed ourselves to develop it by using the autonomy framework due to its reach, complexity and currentness.

\section{OBJECTIVES}

This study aimed at describing:

- Newly graduated nurses' perception of their professional autonomy.

- Newly graduated nurses' perception of the patient's decision-making process.

\section{METHODOLOGICAL PATHWAY}

This article is part of a research project entitled "Nursing care and communication under the bioethical focus".

It is a qualitative study conducted after approval by the Institution's Research Ethics Committee on April 2005 and the signature of Free 
Consent Forms for participation of newly graduated nurses performing in different sectors of a mediumsized public state hospital.

The focal-group strategy was selected for data collection. This technique is recommended for cases in which the researcher considers the possibility of facing occasional difficulties in accessing information of participants with similar experiences by means of individual interviews and observation ${ }^{(9)}$.

The focal group occurred in two meetings. In the first meeting, the moderator promoted the introduction of participants and the presentation of objectives and Bioethics theoretical frameworks. Next, the group members were encouraged to speak and reflect about the care practice in their institution according to the autonomy bioethical framework.

The questions guiding the discussion were:

- Based on the autonomy bioethical framework, tell me about your professional experience.

- Talk about your professional experience in relation to the patient's decision-making process.

The recording of the experiences was made by using a tape recorder. The tapes were fully transcribed and submitted to analysis according to the Grounded Theory methodological framework.

To the creators of the Grounded Theory, this methodology consists in the discovery and development of a theory with basis on systematically obtained and comparatively analyzed information ${ }^{(10)}$.

To them, the theory means "a strategy to deal with research data which provides forms of conceptualization for description and explanation"(10).

They introduce a method of constant comparative analysis where the researcher, when comparing an incident with another incident in the data, establishes conceptual categories that can explain such information. The theory is then generated by an induction process in which analytical categories emerge from the data and are developed as the work advances. Categories are abstractions of the phenomenon observed in the data, and they form the main unit of analysis of the Grounded Theory. The theory is developed by working on the categories, which leads to the emergence of a core category. It is generally a process that results from the analysis ${ }^{(10)}$.

The data analysis phases are: discovering categories, connecting categories, development of memoranda and process identification ${ }^{(10)}$.

This is a process described as theoretical sampling and the researcher decides which data to collect next as a result of the analysis that he has been performing. In this sense, the sampling adopted is not statistical, but theoretical, since the number of subjects or situations that must integrate the study is determined by what they denominated as theoretical saturation, that is, when the information begins to be repeated and new or additional data are no longer found $^{(10)}$.

During data analysis, the authors realized that the content was dense enough in order to understand the experience of the 15 newly graduated nurses as concerns the investigated object.

In view of the evidence, the group of actors was again invited to gather with the purpose to learn about the experience of newly graduated nurses in relation to their autonomy and the patient's. It was suggested that they should express their opinions whether that experience represented the data provided to the researcher. At that moment, they had the opportunity to validate the analysis made by the researchers as well as to discuss the ways for overcoming the problems shown.

\section{RESULTS}

The discussion on professional experience based on the autonomy bioethical framework was developed according to two thematic approaches: A - nurse autonomy and B - patient autonomy.

A - Nurse autonomy

As regards the nurse's autonomy, the concepts which emerged from the experience accounts were organized in the following categories:

A1 - Understanding professional autonomy as an attribute as well as a conquest

Autonomy is understood as something inherent to the individual, and some people seem to be more autonomous than others. A nurse's title is not enough to confer professional autonomy. By solving problems rationally and without impositions, the nurse gradually conquers confidence and achieves greater autonomy. While knowledge favors autonomy, confrontation hinders it. Remaining susceptible and humble to constant learning and the recognition of one's own limits enhance professional autonomy. 
... In my unit, if a doctor comes and tries to examine a patient without washing his hands, as it has happened before, I insist that he do it. Autonomy is achieved by our own selves; there is no point in thinking that others will respect you because you are a nurse.

A2 - Perceiving the existence of some professional autonomy conditioners

A professional's autonomy is developed through respect from auxiliaries and technicians, without authoritarian impositions, and in a friendly and peaceful atmosphere, thus achieving better work organization. Another autonomy conditioner is knowing how to work in teams by following employees during the performance of tasks that they are not familiar with and that a nurse feels more secure doing. A nurse does not acquire professional autonomy when he delegates tasks that he himself does not know how to perform because employees realize it, and the patient may be harmed. A nurse's professional autonomy also depends on the work philosophy adopted in the institution.

If it is necessary to do it, let's do it together; it's team work. What I mean by teamwork is multiprofessional work, not only technicians and auxiliaries, but everyone working together. And thus autonomy is gradually achieved.

In the unit where I work the team is good because the philosophy is also different. The coordinating physician introduced this philosophy. The residents come. I do my job, and they do theirs.

A3 - Making use of professional autonomy

Interventions with physicians, such as reminding them about the adequate performance of certain procedures, observance of intercurrences, etc are conducts related to the use that nurses make of their autonomy. When using their autonomy, nurses must have control over everything that takes place in their work unit, and one of the main reasons for it is to avoid contradiction between the recommendations given to the patient by the physician and the orientation provided by the nurse.

As to physicians, they must realize that we are knowledgeable. For instance: Doctor, look! It is like this, the bandage is applied like this... Also, there is no point in just defying them. We must know what we are talking about, and then there is no argument.

When you are working in a unit, you have to have control over everything, over what is wrong and over what isn't. A reason for it is that the patient himself demands: 'The doctor didn't do this, the doctor didn't do that. Sometimes, patients also report: 'The doctor told me this'. Because the doctor sometimes tells the patients things and does not tell you about it. So you are there and you don't know about it.

A4 - Pointing out the perception of risks to autonomy

Not assuming exclusive assignments or treating employees rudely lead to loss of respect and, consequently, to loss of autonomy. Employees test the capacity and security of novice nurses, make comparisons between new and old nurses, and believe that they are more knowledgeable than newly graduated nurses. Some of the novice nurse's practical difficulties and developing skills are interpreted as lack of knowledge. Novice nurses are also tested by physicians. Therefore, one needs time to achieve autonomy, and even so it will never be absolute.

At the beginning, the auxiliaries and technicians tested us many times, trying to find out how far they could go, up to what extent we were secure and up to what extent we were capable. Many times, in the same way we have to help, we must also say: 'I don't know how to do this.' They take it well. Now, after they get to know me and understand how I work, I feel that it is easier to say: 'I don't know how to do this either, but you can be sure that I will try to learn how to do it'. Because when you assign to someone else the things you don't know how to do, it's plain to see that you can't do it, and they realize it.

In my first year of work, an auxiliary said: 'I have been working here for 25 years, and now you come and want to boss me around?' To them, the time one has worked for the institution means knowledge.

So you just push ahead, you keep discussing with them and showing them reality, that which is correct. Then they begin to trust you, and you achieve autonomy, knowing that your autonomy will never be absolute.

A5 - Pointing out conflicts in the physician/nurse relationship

Disrespect for the nurse's autonomy is more profoundly noted as coming from physicians, making their relationship conflictive particularly in situations in which physicians blame the nursing staff for unsuccessful treatments, do not read the nursing notes and/or do not accept the physical examination performed by nurses. On the other hand, nurses point out physicians' failures to perform procedures, consider that physicians occupy a privileged position in the hospital hierarchy, 
and that they do not have enough time to give patients more dedicated attention. On the other hand, because nurses remain near patients for longer periods, they have better chances to observe in more detail. However, when detecting something that has not been observed by physicians, the nurse may be misinterpreted. Contradictorily, some physicians request that nurses and even auxiliaries and technicians perform procedures that are exclusively medical.

The patient arrives at the surgery, and the physicians do not realize that he has a catheter. This goes unnoticed to them. Then, almost six days later, the patient is to be discharged - 'Is the patient going to be discharged? Doctor, won't the catheter be removed?' - 'Ah, does the patient still have a catheter?' - 'You didn't order its removal...' So, you have to keep telling them. Although we describe the patient's development, they won't read it... That stems from old medical culture. A physician is always in a higher position than everybody else's. It's part of them, and that's it... The other employees are supposed to serve them. - 'I'm telling you to do it, and you do it.' That's the way it is in some places.

In my unit, medical and nursing evaluations are performed. The physician evaluates, and that's it. Then, although I have still not finished the nursing evaluation, I am still evaluating, but the physician evaluates and that's it. He thinks that the nursing evaluation is not necessary. They do not read nursing notes. I think this is part of the medical culture.

One thing they fight about is that they think nurses must not do the physical examination of the patient. Why not? Because we can see many things that they can't, and then we tell them. Many times, they will not accept what we say because it seems like that we are trying to overlook them, who are physicians, so they should have noticed that.

A6 - Pointing out conflicts in the nurse/nursing auxiliary relationship

Conflict stems from interventions by nursing auxiliaries in nurses' conducts and from nurses' perception that they are tested by nursing auxiliaries and technicians in relation to their professional competence.

When a nurse comes, he brings a lot of theoretical knowledge, but many times, he does not have practical skills. So, auxiliaries think they know better and begin to pose questions to make sure that the nurse is really knowledgeable.

\section{A7 - Pointing out other conflicts in the nurse/nurse} relationship

In the relationship with their peers, they identify stronger collectivism among physicians than among nurses. They also perceive other nurses who establish alliances with physicians in order to hurt their colleagues as well as those who refuse to help their colleagues or who lack colleagueship when competing for positions, in addition to the ones who have chosen the profession for the wrong reasons.

Physicians are united, but nurses aren't. One is always trying to show that he is better than the other. Many times a nurse doesn't like another, so he joins a physician to try to cheat the other.

Our salaries are very low, and people want a higher position to earn more, then they end up cheating others.

\section{B - Patient Autonomy}

The concepts concerning patient autonomy which emerged from the discussions are presented in the following categories:

B1 - Perceiving respect from the institution in relation to patient autonomy

It means the evaluative conclusion reached by the nurse that his institution generally respects patient-family autonomy even when it is influenced by religious beliefs. However, some inpatients in specialized units and/or carriers of certain diseases have no autonomy. Nurses must make decisions for the patient in situations of reduced autonomy, but even in such situations, they usually want to hear the opinions of patients' relatives.

There was a patient from the vascular ward who was a Jehovah's Witness and needed a blood transfusion, but she didn't want to have it. Palliative alternative therapy was applied, and transfusion was not made. Only the surgical process was prolonged until the patient could be operated.

I have worked in Intensive Care Units a lot. Patients do not have any autonomy there. They are CVA or hepatic lesion patients, and they don't really have any autonomy. There are few post-operated patients who are sent there and can say: "I want this, I want that'. We do everything for the others. We make their decisions.

On many occasions, we must remain out of the conversation notsay: 'Do this, or not encourage the patient to act in a certain way because something happens later, the family will say; 'that nurse was forcing us to do it.

B2 - Observing nurse/patient/family communication for decision making

In the process of communication with the patient, the nurse many times ends up playing the 
role of a conflict mediator. In such cases, the nurse uses strategies, leading the individual to understand that what is to come later can be worse.

A patient in the Intensive Care Unit needed an endoscopy, but he didn't want to have it. The doctor then talked to him, but he still refused to do it. The nurse and the social worker talked to him, explained the procedure and he accepted. Everything went ok.

\section{B3 - Observing physician/patient/family communication}

Not establishing an effective interpersonal physician-patient-family relationship, which is understood by the nurse as essential while making decisions concerning treatment and recovery, induces the nurse to give explanations to the patient, aiming at re-reading the treatment process defined by the medical team and its re-alignment. Such intervention is almost always effective and has been configured as another activity assigned to the nurse.

The doctor many times orders tests and does not inform the patient about anything. The nurse, on the other hand, informs the patient about what the test is for, what type of test it is. Many times, we explain and I think that it is the nurse's job to explain about tests to patients.

B4 - Pointing out nurses' difficulties in relation to the observance of patient autonomy

It is not always possible to adapt nursing routines to patients' preferences. This can sometimes be done in relation to schedules. In some situations, patients show embarrassment when having to comply with established rules. Nurses find difficulty in answering certain questions asked by patients regarding service rules because they do not agree with them. In such cases, they use strategies such as reducing the time of exposure of the subject to that event or use the persuasion technique; however, without undertaking movements towards changing such routines.

At other times, patients ask: 'But why do I have to take off my underwear if I will have my nose operated. It is difficult to explain... because we don't agree with it either...

This is what we do: As soon as the patient comes from the surgery, we take off his surgery gown, dress him with their pajamas and putt their prostheses back on

\section{DISCOVERING THE CORE CATEGORY}

By inter-relating the categories identified, it was possible to observe two phenomena:

- perceiving the fragility of nurse and patient autonomy;

- moving towards the strengthening of nurse and patient autonomy.

This allowed for the discovery of the core category, which evinced the phenomenon expressed through the movement undertaken by newly graduated nurses towards the strengthening of their own autonomy and towards patient autonomy.

In the condition of newly graduated nurses, they perceive that their autonomy is reduced by exposure among members of a hospital team and by the exposure of their still incipient skills, feeling observed and compared to other more experienced professionals.

Despite regarding autonomy as a personal attribute that is based on private life experiences, they acknowledge that it can be achieved in their work interactions, although it will never be absolute.

During their interactions with the health care team, nurses seek to exert professional autonomy by observing the factors that condition as well as those that reduce it. In these movements, they expose themselves and become involved in conflicts, particularly in situations of asymmetric autonomy and power. When facing conflicts, they perceive the possibilities to identify more appropriate attitudes for the development of their autonomy.

By interacting with patients, nurses observe, analyze and perceive in them their self-determination, which is at times rather reduced due to their health conditions and situation of being institutionalized. Hence, they perceive the patient as also moving away from their fragile autonomy, caused by having to submit to institutional rules, by the care routine established, by difficulties in communicating with members of the health care team and family impositions, towards the achievement of a certain condition to administrate their lives.

Nurses denote to feel powerless to reinforce patient autonomy, but, in this setting, the actors perceive one another, approach one another and become involved in a cooperation and solidarity process, seeking the preservation of each individual's identity and his self-determination. 


\section{DISCUSSION}

Autonomy understood by the nurses participating in this study as a personal attribute means that individuals may present different levels of self-determination, some more than others, according to their life history, social interactions, world views, ideological conceptions, education, economic and social conditions, lifestyles, personalities, etc.

However, when they become professionals, their autonomy will be partly determined by the conception that society has of their profession, which influences the concept that the performers themselves will attribute to their professional activity.

Traditionally, due to its history connected to women's work and also regarded as subaltern, nursing has not received the same consideration as that given to other health care professions by modern and postmodern societies.

Upon completion of an undergraduate program in nursing and their start in the work market, particularly in hospital positions, newly graduated nurses face conflicts stemming from the historical view of their profession, from the institution's organizational power structure, in which power is expressed by policies and rules that are apparently impersonal, but which confirm and ensure the dominant group's power ${ }^{(11)}$.

They submit themselves to hiring processes, training programs and supervision, which are classic forms of maintaining the organization's basic values, but somehow inhibit control over themselves. They will have to show competence and dedication; however, they may be betrayed by skills that were not thoroughly developed during the course of their undergraduate education, thus having to face judgment by their peers and by subordinate personnel and, finally, by the whole health care team.

Over time, they find out that professional autonomy can be achieved by attitudes of respect and by the development of competencies required by the activity, realizing that even so their selfdetermination will never be absolute.

As regards patients' autonomy, additionally to their illness condition which may somehow reduce it, certain actions and attitudes that depersonalize such patients can trigger feelings of insignificance and anger.

Asymmetric relationships are frequently observed between health care professionals and patients, where power is exhibited on one side and submission in on the other.

Many times, professionals assume positions of power over the patient's body, and the latter, in his fragility, does not perceive himself as someone who has autonomy to question, thus passively accepting what is imposed to him and feeling, on many instances, bashful and embarrassed. Such coexistence of autonomy and heteronomy leads to conflicts in a system consisting of an unequal power system which is, at times, disrespectful ${ }^{(12)}$.

Hospitalized patients do not always participate in the decisions made about their lives and are not always communicated about such decisions so as to understand them, and that communication hardly ever occurs dialogically ${ }^{(13)}$.

In this study involving nurses from a public hospital that mostly assists underclass patients who have, therefore, been deprived of their basic life and health conditions, the question presented is: how can nurses lead such patients to autonomy?

It was possible to show that nurses keep certain proximity with inpatients due to the peculiarities of their work, thus establishing ties and assuming cooperation and solidarity attitudes. These conditions can, according to Boemer ${ }^{(4)}$, grant these professionals "a parallel influence power", enabling them to help patients with the exercise of their autonomy, thus encouraging them to learn about and exert their rights.

\section{CONCLUSION}

This study enabled us to understand the experience of newly graduated nurses working at public state hospital and the interpretation that they give to the reality of their practice in relation to their own autonomy and to the autonomy of the patient, the object of their care.

The reflections on the fragility of their autonomy and the patient's self-determination were very important in motivating them to seek new ways for coping with such difficulties.

The ways pointed by the nurses for overcoming the problems identified seem to favor care based on alterity, which enables effective interaction through the practice of symmetrical and dialogical relationships. 
As a result of its number of cases and experiences reported, this study will support our teaching activities as nursing professors by favoring opportunities for reflection with our students on autonomy and nursing practice at the beginning of nurses" professional careers.

\section{REFERENCES}

1. Merigh MAB. Trajetória profissional das enfermeiras obstétricas. Rev Latino-am Enfermagem 2002 setembrooutubro; $10(5)$ :644-53.

2. Lunardi VL, Lunardi Filho WD, Silveira RS, Silva MR Svaldi JSD, Bulhosa MS. Nursing ethics and its relation with power and work organization. Rev Latino-am Enfermagem 2007 maio-junho 2007; 15(3):493-7.

3. Pessini L, Barchifontaine CP. Problemas atuais de Bioética. 7.ed. São Paulo: Loyola, 2002.

4. Boemer MR. O exercício da enfermagem em sua dimensão bioética. Rev Latino-am Enfermagem 1997 março-abril; 5(2):33-8.

5. Spiri WC, Berti HW, Pereira MLD. Os princípios bioéticos e os direitos dos usuários de serviços de saúde. O mundo da Saúde 2006 julho-setembro; 30(30):448-54.

6. Soares JCRS, Camargo JR. A autonomia do paciente no processo terapêutico como valor para a saúde. Interface 2007 janeiro-abril; 11(21):65-78.

7. Seago J, Ann ME. Autonomy: A realistic goal for the practice of hospital nursing. Aquichan 2006 October; 6(1):92-103.

8. Oliver JG, Ballart JF, Barbany JB. Pacientes, medicos Y enfermeros: tres puntos de vista distintos sobre una misma realidad. Actitudes y percepciones ante los derechos de los pacientes. Gac Sanit 2006 November-December; 20(6):46572.

9. Mayan MJ. An introduction to qualitative methods: a training for students and professionals. Edmonton: International Institute for Qualitative Methodology; 2001.

10. Glaser BG, Strauss AL. The discovery of grounded theory. New York: Aldine; 1967.

11. Kurcggant $P$, Massarollo MCKB. Cultura e Poder nas Organizações de Saúde. In: Kurcggant $P$, organizador. Gerenciamento em Enfermagem. Rio de Janeiro, Guanabara Koogan, 2005. p. 26-36.

12. Marchi MM, Srtajn R. Autonomia e heteronomia na relação entre profissional de saúde e usuário dos Serviços de Saúde. Bioética 1998 janeiro-julho; 6(1):39-45.

13. Maffesoli M. Dinâmica da violência. São Paulo: Vértice; 1988 . 